\section{California initiative to probe transgenics in large animals}

[TAHOE CITY, CALIFORNIA] The University of California at Davis has created a centre for transgenic research in large animals, which it hopes will be the first of a nationwide system of university-based facilities advancing biomedical and agricultural science.

Opened last month with university funds, the centre will conduct research in pigs, sheep, goats and potentially cattle, all of which are being studied as sources of proteins, drugs and transplant organs. Its founders hope that the centre will maximize the dissemination of science in a field where many results are closely guarded by the corporations that pay for them.

Davis researchers say they intend to push for a network of four large-animal research centres based at universities across the United States. They see these centres - which would centralize expertise for other universities to use - as a way to save money in an extremely expensive field.

Most US universities use mice, which are cheap and easy to study, for transgenic research. As techniques and results have improved, researchers want to study larger animals. But a single experimental pig can cost more than $\$ 100,000$, a sheep or goat $\$ 75,000$, and a cow anything from $\$ 500,000$ to $\$ 1$ million.

"We want to provide the opportunity for researchers to do a variety of studies" from transgenics to cloning, says James Murray, a Davis geneticist who founded the centre with physiologist Gary Anderson. Both discussed the new centre last week at the university's second Transgenic Animal Research Conference at Tahoe City.

After three years of planning, the centre is being funded initially with about $\$ 750,000$ in campus funds, designated under a special programme for new initiatives. The centre is a collaboration between animal science, the veterinary school and the medical school. Already, researchers from the University of California campuses at San Francisco and San Diego are considering carrying out large-animal projects at the Davis centre. And the Davis team is recruiting researchers for new project grants.

Caird Rexroad, an associate deputy director of the US Department of Agriculture's Agricultural Research Service in Beltsville, Maryland, says he sees the concept as worthy of close study. Research in larger animals "needs to be more efficient to move it along," says Rexroad, a reproductive physiologist.

He adds: "There is a significant role for the public sector in this research to build knowledge to which a lot of people will have access."

R.D.

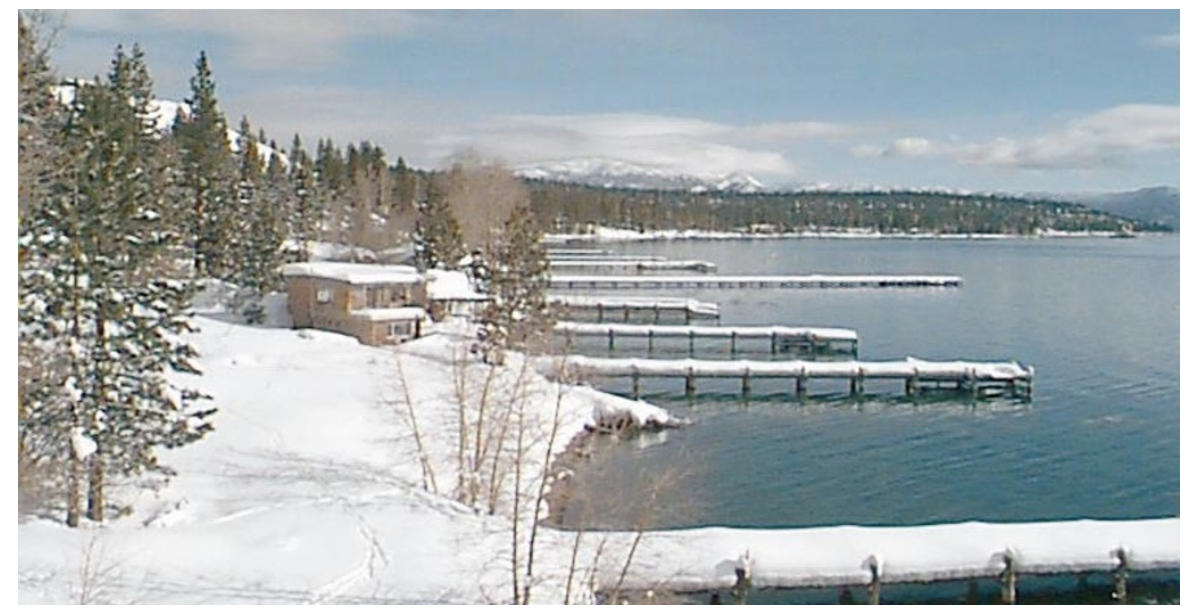

Troubled waters: the University of California at Davis has pledged to continue fundraising for its research centre by Lake Tahoe despite the plan for a rival facility on the Nevada shore.

\title{
University confronts new rival across Lake Tahoe
}

[TAHOE CITY, CALIFORNIA] Plans by the University of California to create a $\$ 12$ million research centre on Lake Tahoe are being complicated by the University of Nevada's decision to build a duplicate centre on the other side of the lake.

The Tahoe Research Group at the University of California at Davis has been studying the ecology of the Tahoe basin, in the mountains between California and Nevada, for 41 years. Limnologists from around the world have used the group's research to address issues of algal growth, lake clarity and pollution.

But earlier this month, the University of Nevada at Reno shocked Davis officials by announcing a plan for a $\$ 10$ million research centre across the lake. Nevada researchers did little work on Lake Tahoe until a couple of years ago, Reno scientists acknowledged, although they have studied the soil and dying forest around the lake.

Charles Goldman, an internationally respected limnologist who directs the Tahoe Research Group, says he was "surprised, to say the least" by Nevada's plans. He added that Nevada's efforts have caused "anxiety" among his philanthropic donors - who have pledged to contribute about half the money needed to rebuild Davis's labs, currently housed in a former fish hatchery built in 1916.

"It is making it more difficult to complete our fund-raising, and it's bad for the science," says Goldman. "But regardless of what Nevada does, we will raise the funds and continue our research."

Davis officials also say that scarce government funds for research on restoring Lake Tahoe will not be used efficiently if duplicate overhead costs are needed for the proposed Nevada facilities.

^ ๔ 1999 Macmillan Magazines Ltd
But Glenn Miller, who directs the University of Nevada's Center for Environmental Sciences and Engineering in Reno and is involved in planning the lake facilities, says his university wants to play a more active role in studying Lake Tahoe. "There is some value in diversity," says Miller, an environmental chemist. "We have different expertise."

Nevada began planning its centre more than two years ago, when President Bill Clinton and Vice-President $\mathrm{Al}$ Gore visited the lake and called for more ecological restoration efforts. As Davis and Nevada scientists subsequently discussed ways to improve lake ecology, Nevada officials were discreetly planning their own facility, garnering support from an unnamed Reno foundation which will donate the $\$ 10$ million.

The University of Nevada plans to build a research facility, conference centre and offices on federal land on the Nevada side of the lake near Round Hill. A smaller research facility is also planned for a second site nearby that is to become public land.

Miller - a Davis graduate - acknowledges some embarrassment at the rivalry between the two universities. When Nevada's plans were revealed this month at a political meeting between representatives of the two states to discuss Lake Tahoe restoration, some University of Nevada officials denigrated the Davis plans, telling the press that they didn't "have to be friendly" with the California team. Miller calls such comments "stupid”, lauding "top-flight research" by Goldman and his team.

Some observers wonder why Nevada did not combine forces with Davis. But it seems probable that the University of Nevada wants to boost its share of government research funds associated with a proposed $\$ 900$ million restoration of the lake.

Rex Dalton 